Gadjah Mada International Journal of Business

January-April 2008, Vol. 10, No. 1, pp. 1-23

\title{
DRIVERS OF MERGER WAVES A Revisit
}

\author{
Soegiharto
}

This study reexamines whether the occurrence of merger waves can be explained by the neoclassical hypothesis or the behavioral hypothesis. Using merger data for the period spanning 1990 through 2001, this study directly compares the two theories and finds that, in general, merger waves occur at the time the capital liquidity is high, firms' stocks are overvalued, and deregulatory events exist. These suggest that the existence of an economic motivation for transactions and the availability of lower transaction cost and/or overvalued stock to generate large volume of transactions may cause industry merger waves to cluster in time

Keywords: industry shocks; market misvaluations; merger; merger waves 
Gadjah Mada International Journal of Business, January - April 2008, Vol. 10, No. 1

\section{Introduction}

Recent research on mergers has focused on the cause of their occurrence in waves. Two theories have been proposed, one consistent with neoclassical economics and the other based on assumptions derived from behavioral finance theory. The neoclassical theory proposes that the impetus for merger waves stems from shocks to the economic, technological, and/or regulatory environment of an industry while the behavioral finance based theory proposes that merger waves are a function of market misvaluation of bidder and target firms (Shleifer and Vishny 2003).

This study replicates that of Harford (2005) who examined whether merger waves during the 1980s and 1990s were driven by industry shocks or stock market misvaluation. Based on his results, Harford concludes that industry shocks in conjunction with time-varying changes in capital liquidity are accounted for merger waves better than behavioral factors. In contrast, the results reported in this study, which uses merger data for the period spanning 1990 through to 2001 indicate that merger waves are driven by stock market misvaluation, higher capital liquidity, and the presence of deregulatory event. Nevertheless, the results from univariate analysis indicate that the abnormally high changes in variables related to the neoclassical hypothesis (e.g. sales growth) may also drive merger waves. In general, firms attempt to improve their performance by undertaking mergers when capital liquidity is high, their stock is overvalued, and deregulatory events exist. The existence of an economic motivation for transactions and the availability of lower cost transaction and/or overvalued stock to generate large volume of transactions may cause industry merger waves to cluster in time.

\section{Literature Review}

Although it is well documented that merger activity occurs in waves that tend to be concentrated in industries and the industries have been different in each of the major waves identified to date, there is no consensus as to why merger waves occur. Neoclassical economists favor structural rather than behavioral explanations and they posit that a high proportion of mergers are a reaction to shocks (i.e., economic upheavals) that alter equilibrium industry structure. Other economists propose that merger waves are a function of market inefficiency and that periods of high merger activity are driven by incidences of unusually high market misvaluations. The two explanations are not mutually exclusive but their respective proponents differ on the extent to which the explanations account for mergers.

\section{Neoclassical Explanation of Merger Waves and Empirical Evidence}

Principal papers advocating the neo-classical perspective on merger waves include Gort (1969), Morck et 
al. (1988), and Jensen (1993). Gort (1969) is the first study to document interindustry variation in the rate of takeover activity and the first to observe that merger waves are consistent with an economic disturbance model. In line with Gort's theory, Morck et al. (1988) posit that a key determinant of merger, takeover and LBO activity in the 1980s was the need to restructure industries that had experienced adverse economic shocks. Similarly, Jensen (1993) contends that most merger activity since the mid-1970s has been caused by technological and supply shocks.

Later studies investigated the industry shock hypothesis in more detail. Mitchell and Mulherin (1996) update Gort's analysis by assessing whether industry shocks contributed to the extensive takeover activity of target firms over the period 1982 through to 1989. Consistent with Gort's theory, they find that the variations in takeover activity across industry and in the time-series pattern of takeovers by industry during the 1982 to 1989 sample period are significant. Similarly, Andrade and Stafford (2004) examined whether industry-wide forces precipitated merger activity of acquiring firms during the 1970-1994 period. Both studies test whether takeover and restructuring activity is higher in industries that experience shocks of the greatest magnitude. Andrade and Stafford (2004) find strong support for the existence of both expansionary and contractionary motivations for merger activity. Their analysis reveals that the relative importance of each of the merger roles changes over time, depending on economic conditions.

To investigate more closely the relation between takeover activity and industry shocks, Mitchell and Mulherin (1996) and Andrade and Stafford (2004) developed a proxy for industry shocks based on sales data. Both studies find a direct relationship between sales shocks and industry takeover activity. In addition, Mitchell and Mulherin (1996) documented a direct relationship between employment shocks and industry merger activity. To identify the sources of industry change that lead to takeover activity, Mitchell and Mulherin (1996) then investigated the impact of likely shockinducing factors such as deregulation, energy price volatility, foreign competition, and financing innovations. Their analysis shows that specific shocks such as deregulation and financing innovations contributed to the high incidence of takeovers and restructuring activity during the 1980s. These findings provide substantial empirical evidence in support of Jensen's (1993) proposition that most merger activity since the mid-1970s has been caused by technological, regulatory, and broad economic changes that have had disproportionately large impact on certain industries. Andrade and Stafford (2004) also support this framework by finding that related-industry mergers follow industry shocks and occur in times of excess capacity, which is consistent with their hypothesis of contractionary motive for mergers. 
In similar vein to the study of Mitchell and Mulherin (1996) and Andrade and Stafford(2004), Mulherin and Boone (2000) measured the impact of economic shocks on corporate restructuring activity by studying whether there are industry patterns in the rate of not only acquisitions but also divestitures during the 1990 to 1999 period. Their consideration of both acquisitions and divestitures and emphasis on 1990s distinguishes their work from previous studies. Their results show that almost half of the sample firms were acquired and/or engaged in a major divestiture, a finding similar to that reported by Mitchell and Mulherin (1996) who document that about half of their sample firms experienced a takeover attempt during the 1982 to 1989 period. These results show that the U.S. corporate restructuring in the 1990s is comparable to the significant merger movements that take place in the 1980s. Moreover, Mulherin and Boone (2000) confirm the industrylevel clustering of mergers for the 1990s by finding a significant variation in takeover activity as well as in divestiture.

Mulherin and Boone (2000) also attempted to identify the sources of inter-industry variation in acquisition activity and consider whether acquisition activity in the 1990s is driven by similar factors as the 1980s. They identify deregulation and rapid change in technology which lead to industry overcapacity as the main factors that stimulated acquisition activity in 1990s and find that deregulation has a significant and positive effect on the acquisition activity in the 1990s, consistent with the 1980s. They also compared the rate of acquisition activity across industries in 1980s and 1990s and confirm that while there is significant restructuring activity in both the 1980s and 1990s, there is not a one-to-one relation in the affected industries. This is consistent with the finding of Andrade et al. (2001) that industries that demonstrate high degrees of merger activity in one decade are no more likely to do so in other decades. Andrade et al. (2001) confirm the industry-level clustering of mergers for the 1990s by providing evidence that merger activity in the 1990s, as in previous decades, is strongly clustered by industry and find deregulation as a key driver of merger activity over that decade.

Similar to the studies above, Harford (2005) also investigated the causes of merger waves. He applied a random simulation procedure to identify merger waves in industries during the 1980 s and 1990 s. He finds 35 waves from 28 industries, with seven industries experiencing two distinct waves. He identified reasons for the emergence of waves by analyzing news reports around the time of each wave and undertook some tests that directly compared the neoclassical model and the behavioral model. His results support a neoclassical explanation of merger waves that merger waves occur in response to specific industry shocks that require large-scale reallocation of assets. However, a puzzle 
that the standard neo-classical theory unable to address is why waves should be significantly more concentrated in time than the ostensible economic shocks that prompt them. Harford posits that restructurings require capital liquidity to implement and that shocks only propagate a merger wave when economic conditions generate sufficient capital liquidity to accommodate the necessary transactions (the reallocation of assets). His results support this interpretation.

In sum, Harford's interpretation of neoclassical theory provides a plausible explanation of shocks as the driver of industry merger waves. Nevertheless, the theory still does not account for significant features of takeover waves such as whether cash or stock is used as medium of payment. Furthermore, the theory does not explain aggregate merger waves unless it is assumed that a group of industries experience shocks simultaneously. A behavioral explanation of merger waves that accommodates factors ignored in the neoclassical theory has been proposed by Shleifer and Vishny (2003) and Rhodes-Kropf and Viswanathan (2004). It is discussed in the following section.

\section{Behavioral Explanation of Merger Waves and Empirical Evidence}

The positive correlation between merger activity and stock valuation has been noted by Melicher et al. (1983), Becketti (1986), and Golbe and White (1988). Recent theoretical work by Shleifer and Vishny (2003) and Rhodes-Kropf and Viswanathan (2004) have addressed this correlation. Shleifer and Vishny (2003) proposed that market misvaluation drives merger transactions. The theory assumes that significant information asymmetry exists among stock market participants and the presence of selfinterested, informed target managers who exploit their superior knowledge to profit themselves at the expense of shareholders. The theory works as follows, information asymmetry occurs. Managers know the true value of their own firms and that of potential target or acquirer firms. They also know the extent of the divergence of the shortrun valuation of their firm from the long-term and the synergies available to be exploited. They use this information to maximize their personal wealth. Given these conditions, Shleifer and Vishny (2003) posit that target managers sell their firms for stock in a longrun manager's firm when both firms are overvalued even though the transaction price gives the short-run manager less than he knows his firm will be worth in the long run. The target manager profits by selling his acquired shares into the overvalued market. Since the market is inefficient, it does not react to this deception over the target managers' relevant horizon.

Shleifer and Vishny (2003) point out that their theory explains several otherwise puzzling elements in takeover waves, including the fact that they are highly concentrated in time, cluster during high stock market valuations period, and generally use stock 
as medium of payment, as pointed out by Nelson (1959) and confirmed by Andrade et. al. (2001). The evidence that merger activity, especially mergers for stock, is correlated with the level and dispersion of stock market valuations as documented by Verter (2002) which is also consistent with their model.

Another theoretical model in which the target underestimates (overestimates) market-wide overvaluation when the market is overvalued (undervalued) is proposed by Rhodes-Kropf and Viswanathan (2004). Their approach is based on a rational model of mergers financed with stock and is built on the idea that only limited information is available for targets in their attempt to value offers. In this model, private information is on bidder and target rationally leads to a correlation between stock merger activity and market valuation. Although the target's and bidder's private information tells them whether they are overvalued or undervalued, they cannot separately identify the sources of the misvaluation. As the target firm has limited information about the components of the misvaluation, it has difficulty in assessing the synergies which are critical in the model. Errors in valuing potential takeovers synergies are correlated with overall valuation error. A large number of valuation errors may cause merger waves because ex post, targets have mistakenly over-estimated synergies. In short, this model incorporates both firm-specific and market-wide misvaluation as con- tributing factors to merger waves.

Although the theories of Shleifer and Vishny (2003) and Rhodes-Kropf and Viswanathan (2004) do not model the source of market misvaluation and economically to be very different, they yield parallel empirical predictions on the link between misvaluation and mergers. In the theory of Shleifer and Vishny (2003), highly overvalued firms, whose shareholders are assumed to be long-term investors, appear as a result of market misvaluation. Less overvalued targets with short-term shareholders are acquired by these overvalued firms. The theory predicts that, in cash acquisitions, bidders attempt to profit by buying targets that are undervalued in absolute terms (i.e., relative to fundamentals) or by buying target that are undervalued (less overvalued) relative to the bidders in stock acquisitions. Target managers accept payment with stock if the target is also overvalued. This transaction gives target management the chance to 'cash out' of their illiquid stock or options. More generally, the misvaluation hypothesis reflects the insight that the willingness of target management to cash out should tend to be greater when the target is less undervalued (or more overvalued). In addition, stock acquisitions are more likely to occur when a large dispersion of valuations exists in the market, signs of overvaluation relative to fundamental are shown by the bidders, and bidders either have relatively longer horizons than those of the targets, or alternatively pay off target managers to consent to the stock 
merger. Generally, these predictions are consistent with the theory of Rhodes-Kropf and Viswanathan (2004).

Three studies that empirically examine market misvaluation theory are Ang and Cheng (2003), Dong et al. (2002), and Rhodes-Kropf et al.(2004). Ang and Cheng (2003), using a merger sample covering the years 1984 to 2001, examined how misvaluation affects merger transactions. They used the price-to-book (P/B) ratio and residual income model (RIM) as measures for overvaluation. They also examined whether and how overvalued bidders create or destroy wealth for their shareholders using the long-term abnormal return of the combined firms. Dong et al. (2002), also examined the effects of market misvaluation on merger activity and estimated misvaluation using the ratio of book value of equity to price and the ratio of residual income value to price for the period of 1978 to 2000. Their investigation covered a wide set of takeover characteristics such as merger vs. tender offers and hostile vs. friendly takeovers. Using a sample of mergers for the period of 1978 to 2001, RhodesKropf et al. (2004) examined how firm and industry valuation relate to level of merger activity and medium of payment. They also used market-to-book ratio to explore misvaluation empirically.

Ang and Cheng (2003) document that the trend of targets' overvaluation over the years is different to that of acquirers' overvaluation. This suggests that the acquirers not only acquire targets that rise with the market, but also look for bargains. They argue that the underlying premise in Rhodes-Kropf and Viswanathan (2004) on the inability of the target firms to differentiate the effects of market overvaluation on firm value from synergy is supported by their evidence. They also find that acquirers, on average, are overvalued based on both absolute (P/B) and relative measures (RIM) which supports their hypothesis that acquirers are more overvalued than the targets. A similar result is also documented by Dong et al. (2002) who find that overvaluation is present in both cash and stock offers but is stronger among stock offers. Moreover, Ang and Cheng (2003) find that acquirers are more overvalued than non-acquirers and after they control for other factors, such as industry effect, that may potentially affect the firm's decision to acquire, the probability of a firm becoming an acquirer significantly increases with its degree of overvaluation.

Since overvalued acquirers can only profit from their misvaluation by paying for their target firm with their stock, Ang and Cheng (2003) and Dong et al. (2002) postulate and verify that stock-paying acquirers are substantially more overvalued then cash-paying acquirers. Ang and Cheng's (2003) logistic regression analysis shows that the probability of stocks being utilized as the payment method significantly increases with the acquirer's overvaluation. Both studies also document that targets who receive cash bids are sig- 
Gadjah Mada International Journal of Business, January - April 2008, Vol. 10, No. 1

nificantly more undervalued than targets offered stock as consideration. In addition, Ang and Cheng (2003) find less overvaluation of targets than their acquirers in both cash and stock mergers. Dong et al. (2002) also document the association between target overvaluation and the use of stock as well as the relationship between target undervaluation and the use of cash as a means of payment. They also find that acquirers with higher estimated overvaluation are more likely to offer stock instead of cash as the sole form of consideration and that acquirers are more willing to pay higher premiums. The former finding is consistent with bidders attempting to profit by ex- changing stock that is overvalued for target assets. Rhodes-Kropf et al. (2004) also document findings similar to the Ang and Cheng (2003) and Dong et al. (2002) studies by confirming the occurrence of merger waves when market valuations are high relative to "true" valuations. However, they note that their results are not only consistent with the behavioral mispricing theory but also with the interpretation that merger activity spikes when growth opportunities are high or when firmspecific discount rates are low. This latter interpretation is similar to a neoclassical hypothesis with a capital liquidity component.

\section{Table 1. Predictions and Findings of the Neoclassical and Behavioral Hy-} potheses for Merger Waves

\begin{tabular}{|c|c|c|c|}
\hline & Neoclassical & Behavioral & Finding \\
\hline $\begin{array}{l}\text { Reason for industry } \\
\text { wave }\end{array}$ & $\begin{array}{l}\text { Regulatory or economic } \\
\text { shock accompanied by } \\
\text { capital liquidity }\end{array}$ & $\begin{array}{l}\text { Overvaluation and } \\
\text { dispersion of valuation } \\
\text { within industry }\end{array}$ & $\begin{array}{l}\text { Regulatory, economic } \\
\text { shocks, capital liquidity, } \\
\text { stock, overvaluation }\end{array}$ \\
\hline $\begin{array}{l}\text { Reason for aggregate } \\
\text { wave }\end{array}$ & $\begin{array}{l}\text { Multiple simultaneous } \\
\text { industry waves clustering } \\
\text { because of macro } \\
\text { liquidity factor }\end{array}$ & $\begin{array}{l}\text { Overvaluation and } \\
\text { dispersion in the } \\
\text { aggregate }\end{array}$ & $\begin{array}{l}\text { As aggregate clustering } \\
\text { of merger activity is } \\
\text { strongly explained by } \\
\text { the industry-level merger } \\
\text { wave, it is suggestive that } \\
\text { the cause of aggregate } \\
\text { wave similar to the cause } \\
\text { of industry wave }\end{array}$ \\
\hline $\begin{array}{l}\text { Pre-wave market-to-book } \\
\text { ratios }\end{array}$ & $\begin{array}{l}\text { High if capital liquidity } \\
\text { is tied to asset valuation }\end{array}$ & High & High \\
\hline Measures of tight credit & $\begin{array}{l}\text { Low if capital liquidity } \\
\text { is important }\end{array}$ & No Prediction & Low \\
\hline $\begin{array}{l}\text { Post-merger operating } \\
\text { performance }\end{array}$ & $\begin{array}{l}\text { Better than without a } \\
\text { merger }\end{array}$ & Worse in waves & Mixed \\
\hline
\end{tabular}




\section{Predictions}

The predictions of the neoclassical and behavioral hypotheses of merger waves in this study are similar to those of Harford (2005) and summarized in Table 1 . The empirical findings of this study which are discussed in Section 5 are also previewed in the Table 1.

\section{Data and Tests for the Presence of a Merger Wave}

This study uses data on merger activity from the Securities Data Company's (SDC) Platinum. The database provides a comprehensive source of information on various aspects of merger activity such as mode of payment, attitude of the deal, and source of funds. In addition, it covers merger activity across the world's major financial markets. The data gathered in this study includes information about successful US merger transactions that took place during the period of January 1990 to December 2001 with a value of transaction at least US\$50 million. The merger transactions selected are those involving listed acquirer and target firms. Companies are grouped into 48 industries as per Fama and French (1997), based on SIC codes.

Harford's (2003) simulation procedure is followed to identify merger waves. It is implemented as follows. Each bidder and target is sorted into one of 48 industry groups, based on their respective SIC codes at the time of the bid announcement. Bidders and targets from industries are assigned to their own industry. For each industry, the highest concentration of completed merger bids involving firms in that industry within a 24-month period (overlap) is identified and tagged as a potential wave. To confirm a potential wave as an actual wave the following simulation procedure is followed to construct a distribution of merger concentrations that facilitates testing of the economic significance of each merger wave concentration. The total number of merger bids for a given industry over the 144-month sample period (i.e., 12 years x 12 months) is identified. Each bid is then randomly assigned to one of the 144-months with the probability of assignment being $1 / 144$ for each month. This is repeated 1000 times. Then, the highest concentration of merger activity within a 24-month period from each of the 1000 draws is calculated. The actual concentration of activity from the potential wave is compared to the empirical distribution based on the simulated data. If the actual peak concentration exceeds the $95^{\text {th }}$ percentile from that empirical distribution, that period is coded as a wave. For instance, the cluster of completed merger bids in the Communications industry is coded as a wave because the 34 percent mergers (57 out of 168) that occurred within one 24-month period, starting in July of 1997 , is greater than the $95^{\text {th }}$ percentile of maximum concentration within any 24-month period based on the empirical distribution which is only 28 percent. The final result of the mergers 
Gadjah Mada International Journal of Business, January - April 2008, Vol. 10, No. 1

\section{Table 2. Industries' Merger Wave}

\begin{tabular}{|c|c|}
\hline Industry & Start and The Cause of the Wave \\
\hline Aircraft & $\begin{array}{l}\text { Jan, } 1999 . \text { Big, older fleets require increased maintenance, repair } \\
\text { and overhaulIncreasingly outsourced from carriers, who want } \\
\text { "one-stop shops"” }\end{array}$ \\
\hline Banking & Oct, 1996. Deregulation and Information Technology (IT) \\
\hline Business Services & $\begin{array}{l}\text { Sep, 1998. Fragmented, smaller players combine, share cost } \\
\text { structures, offer more complete line of services to customers- } \\
\text { industry grows as outsourcing takes off }\end{array}$ \\
\hline Business Supplies & $\begin{array}{l}\text { Feb, 1997. Paper and pulp industry consolidates from fragmented } \\
\text { price takers to gain market power and avoid costly duplication of } \\
\text { capital intensive production facilities }\end{array}$ \\
\hline Chemicals & $\begin{array}{l}\text { Mar, 1995. Large cash flows, over capacity in production, need } \\
\text { to consolidate research }\end{array}$ \\
\hline Communication & $\begin{array}{l}\text { July, 1997. Deregulation: Telecommunications Act in 1996, } \\
\text { consolidation, technological changes }\end{array}$ \\
\hline Computers & Jun, 1998. Internet \\
\hline Electronic Equipment & $\begin{array}{l}\text { Feb, 1999. OEM's growth leads to demand for electronic equip- } \\
\text { ment manufacturers to shift from small regional players to larger } \\
\text { global players capable of infrastructure, IT, etc. to grow with } \\
\text { their customers }\end{array}$ \\
\hline Entertainment & $\begin{array}{l}\text { Mar, 1998. Studios seek diversified production sources and } \\
\text { strong libraries; Telecom act of } 1996 \text { relaxes media ownership } \\
\text { limits }\end{array}$ \\
\hline Food Products & $\begin{array}{l}\text { Jan, 1999. Retail consolidation pushes distribution consolidation } \\
\text { and/or sale of distributors to bigger retailers who want to buy } \\
\text { rather than build distribution channels }\end{array}$ \\
\hline Healthcare & $\begin{array}{l}\text { May, 1996. Service providers consolidate to have bargaining } \\
\text { power with HMOs }\end{array}$ \\
\hline Insurance & $\begin{array}{l}\text { Nov, 1998. Bigger is safer, leading to consolidation, especially in } \\
\text { re-insurers }\end{array}$ \\
\hline Machinery & $\begin{array}{l}\text { May, 1996. Large manufacturers decreased number of suppliers } \\
\text { they were willing to deal with in bid to improve efficiency. This } \\
\text { forced consolidation in a number of capital goods industries- } \\
\text { many smaller players were bought in "roll-up" deals }\end{array}$ \\
\hline
\end{tabular}




\section{Continued from Table 2}

\begin{tabular}{|c|c|}
\hline Industry & Start and The Cause of the Wave \\
\hline $\begin{array}{l}\text { Measuring and } \\
\text { Control Equipment }\end{array}$ & Oct, 1998. Depression in semiconductor industry (big customer) \\
\hline Medical Equipment & $\begin{array}{l}\text { Nov, 1998. Two motives: first, acquisitions in core areas to grow, } \\
\text { then acquisitions outside core areas to offer broad products to } \\
\text { increasingly consolidated customer base (hospitals) }\end{array}$ \\
\hline Personal Services & Feb, 1996. Consolidation in legal and funeral services industries \\
\hline $\begin{array}{l}\text { Petroleum and } \\
\text { Natural }\end{array}$ & $\begin{array}{l}\text { June, 1997. Increasing prices, record drilling, increasing costs } \\
\text { lead drive to increase size to be more efficient }\end{array}$ \\
\hline Pharmaceutical & $\begin{array}{l}\text { Oct, 1998. Mid-sized companies merge to garner size necessary } \\
\text { to fund }\end{array}$ \\
\hline Products & increasingly large costs of development \\
\hline Restaurant, Hotels, & $\begin{array}{l}\text { Dec, 1996. Operators such as Starwood have buying sprees. } \\
\text { Others buy }\end{array}$ \\
\hline Motels & $\begin{array}{l}\text { properties to gain sufficient bulk to compete in corporate account } \\
\text { business market }\end{array}$ \\
\hline Retail & Aug, 1996. Strong growth and impact of internet \\
\hline $\begin{array}{l}\text { Shipbuilding, } \\
\text { Railroad Equipment }\end{array}$ & $\begin{array}{l}\text { Aug, 1998. Shrinking defence budgets finally forced the issue of } \\
\text { overcapacity in the industry }\end{array}$ \\
\hline Steel Works & $\begin{array}{l}\text { Sep, 1997. Collapse in demand from Asia leads to falling prices } \\
\text { forcing consolidation }\end{array}$ \\
\hline Transportation & $\begin{array}{l}\text { July, 1997. End of Interstate Commerce Commission, overca- } \\
\text { pacity in shipping, open skies agreements, railroad consolidation } \\
\text { started with a few big mergers and then forced responses to } \\
\text { balance }\end{array}$ \\
\hline Utilities & $\begin{array}{l}\text { Nov, 1997. Deregulation in some markets plus elimination of a } \\
\text { law prohibiting mergers between noncontiguous providers }\end{array}$ \\
\hline Wholesale & $\begin{array}{l}\text { June, 1996. Simultaneous consolidation in several wholesale } \\
\text { sectors as growth slows and firms move to add breadth, take } \\
\text { advantage of new IT ability, grow by acquisition }\end{array}$ \\
\hline
\end{tabular}

The procedure described in Section 4 results in industries with merger wave and starting dates of the merger wave. The reasons for the wave to occur are taken from Harford (2005). 
simulation is 25 waves, as can be seen in Table 2. Another industry, Candy and Soda, claimed by Harford to have a merger wave in the 1990s does not appear in the simulation result. The average number of bids during the 24month wave period over the 12-years sampling period is 40 whereas the average number of bids during the 24month non-wave period is 15.29.

\section{Results}

This study examines a set of factors predicted by the neoclassical theory to be related to merger waves. These factors include net income to sales, asset turnover (sales divided by beginning-of-period assets), research and development (scaled by beginning-of-period assets), capital expenditures (scaled by beginning-of-period of assets), employee growth, return on assets, and sales growth. These factors are argued to capture economic shocks to operating environment of an industry and the selection of these factors is motivated by studies of Healy et al. (1992), Clark and Ofek (1994), and Switzer (1996) who investigated the changes in the performance of acquiring and target firms around mergers and Mitchel and Mulherin (1996) who assessed whether industry shocks, proxied by sales and number of employee, contributed to the extensive merger activity in 1980s. The marketto-book ratio is also another potential economic characteristic to capture industry shocks. However, interpretation of this variable is ambiguous as it is also claimed by the behavioral hypothesis.

\section{Univariate Evidence}

In this section, the set of industry characteristics prior to merger wave are examined. The variables are examined in the year before the start of an industry's merger wave. As each of the 25 industries over the 12-year sampling period has one wave, there are 25 industry-years preceding the start of a merger wave. The median absolute change in each of the variables in the set is used to measure economic shocks because the consequences of shocks could be different across firms and the average directional implication could also be different due to the different shocks across industries. The results of the test are presented in Table 3 and the number presented in the table is the mean, across all industries, of this industry-specific median in the year immediately prior to the start of the merger wave. The 12-year time-series of shock observations for each industry are also ranked into quartiles and the crossindustry mean rank of the shock in the pre-wave year is presented. As shown in the table, the variables in which the changes are abnormally high prior to each wave include capital expenditures, employee growth, and sales growth (at 0.05 level). The time-series ranks for these three variables show that the pre-wave changes are high for the average industry. In addition, market-to-book, the variable that is related to both the neoclassical and behavioral hypotheses, is the only variable in 
which the change is abnormally high in the year preceding a wave. The time series-rank in the table indicates that the pre-wave change for this variable is also high for the average industry. The findings in this univariate test only support some of the findings in
Harford (2005). In his study, Harford finds that all changes in the variables that are related to the neoclassical hypothesis and to both the neoclassical and behavioral hypotheses are abnormally high before the wave (at 0.1 level).

Table 3. Economic Shocks Measures and Market-to-Book

\begin{tabular}{|c|c|c|c|c|c|}
\hline $\begin{array}{l}\text { Economic Shocks } \\
\text { (Variables related to } \\
\text { the neoclassical } \\
\text { hypothesis) }\end{array}$ & Mean & Rank & $\begin{array}{l}\text { Market-to-Book variables } \\
\text { (Variables related to both } \\
\text { neoclassical and behavioral } \\
\text { hypotheses) }\end{array}$ & Mean & Rank \\
\hline $\begin{array}{l}\text { Net Income to Sales } \\
\mathrm{H}_{0}: \text { Rank }=2.5\end{array}$ & 0.065 & $\begin{array}{r}2.44 \\
{[0.822]}\end{array}$ & $\begin{array}{l}\text { Market-to-Book } \\
\mathrm{H}_{0}: \text { Rank }=2.5\end{array}$ & 0.730 & $\begin{array}{r}3.04 \\
{[0.012]}\end{array}$ \\
\hline $\begin{array}{l}\text { Asset Turnover } \\
\mathrm{H}_{0}: \text { Rank }=2.5\end{array}$ & 0.169 & $\begin{array}{r}2.80 \\
{[0.170]}\end{array}$ & $\begin{array}{l}\text { Change in Market-to-Book } \\
\mathrm{H}_{0}: \text { Rank }=2.5\end{array}$ & 0.457 & $\begin{array}{r}2.20 \\
{[0.201]}\end{array}$ \\
\hline $\begin{array}{l}\text { Research \& Development } \\
\mathrm{H}_{0}: \text { Rank }=2.5\end{array}$ & 0.016 & $\begin{array}{r}2.44 \\
{[0.802]}\end{array}$ & $\begin{array}{l}\text { Industry } \sigma \text { (Market-to-Book) } \\
\mathrm{H}_{0}: \text { Rank }=2.5\end{array}$ & 18.352 & $\begin{array}{r}2.24 \\
{[0.295]}\end{array}$ \\
\hline $\begin{array}{l}\text { Capital Expenditure } \\
\mathrm{H}_{0}: \text { Rank }=2.5\end{array}$ & 0.026 & $\begin{array}{r}3.04 \\
{[0.003]}\end{array}$ & & & \\
\hline $\begin{array}{l}\text { Employee Growth } \\
\mathrm{H}_{0}: \text { Rank }=2.5\end{array}$ & 0.174 & $\begin{array}{r}3.28 \\
{[0.001]}\end{array}$ & & & \\
\hline $\begin{array}{l}\text { Return on Assets } \\
\mathrm{H}_{0}: \text { Rank }=2.5\end{array}$ & 0.054 & $\begin{array}{r}2.72 \\
{[0.381]}\end{array}$ & & & \\
\hline $\begin{array}{l}\text { Sales Growth } \\
\mathrm{H}_{0}: \text { Rank }=2.5\end{array}$ & 0.183 & $\begin{array}{r}2.84 \\
{[0.046]}\end{array}$ & & & \\
\hline
\end{tabular}

The variables are used to measure economic shocks to the industry: net income to sales (profitability), asset turnover, research and development, capital expenditures, employee growth, return on assets, and sales growth. For each industry-year, the median absolute change in each of above variables is computed. Market-to-book and dispersion in market-to-book are either economic variables or misvaluation proxies. For all variables, the number presented in the table is the mean, across all industries, of this industry-specific median in the year immediately preceding the start of the merger wave (there are 25 industry-year observations for this pre-wave year). For each industry, the 12-year time series of shock observations is ranked into quartiles and the table presents the crossindustry mean rank of the shock in the pre-wave year. As in Harford, a test is performed on the average difference between a rank of 2.5 (middle) and the ranking of the pre-wave year within its own industry time series. The $p$-value for the hypothesis that this difference is zero is presented in brackets. 
To test whether a macro component (proxy for capital liquidity) may explain merger waves, Harford(2005) applied the capital liquidity arguments advanced by Shleifer and Vishny (1992) and Eisfeldt and Rampini(2003) to the analysis of merger waves. The proxy for liquidity that he used is the spread between the Federal Funds rate and the average interest rate on commercial and industrial loans. As stock mergers do not require access to the credit markets, Harford does not assert that the accessibility of commercial and industrial credit have a direct causal effect on merger activity. Instead, based on the results of the Lown et al. (2000) who find the degree to which the Senior Loan Officer survey reports tightening is strongly correlated with the spread between the average interest rate on commercial and industrial loans and the Federal Funds rate, Harford argues that the rate spread may be used as a proxy for overall liquidity or ease of financing in the economy and the rate spread will be correlated with transaction costs in the neoclassical model with transaction costs. Because higher asset values accommodate capital liquidity in an industry, Harford also includes an industry-specific interaction variable that accounts for the valuation levels in the industry in the empirical specifications to test the model.

Following Harford, the four-quarter moving average of the rate spread is plotted against aggregate merger activity and is presented in Figure 1. Consistent with Harford's findings, an inverse relation between the rate spread and aggregate merger activity is evident in Figure 1. An increase in merger activity is preceded by a decrease in the rate spread and the end of a merger wave is indicated by an increase in the rate spread $(\mathrm{r}=-0.461, \mathrm{p}=0.012)$.

It may be expected that the rate spread, the proxy for transaction costs, is correlated with some of the key variables in the behavioral models. As shown in Figure 2, the rate spread is correlated with both overall median market-to-book and the three-year compounded return on the S\&P 500 index. The correlation between lagged changes in the rate spread and current changes in the market-to-book ratio is strongly significant $(r=-0.548, \mathrm{p}=$ 0.028 ) and the reverse, the correlation between lagged changes in the marketto-book and current change in the rate spread is also strongly significant $(\mathrm{r}=$ $-0.655, \mathrm{p}=0.006$ ). Therefore, inconsistent with Harford, it is hard to say whether the decrease in the rate spread leads to increases in the market-tobook ratio or vice versa. However, the correlation between lagged changes in the rate spread and current changes in the S\&P500 is strongly significant $(\mathrm{r}=-0.666, \mathrm{p}=0.005)$ and the reverse is not true, the correlation between lagged changes in the S\&P500 and the current changes in the rate spread is an in-significant -0.057 . Based on these last two correlations, it can be said that that the rate spread precedes the S\&P500 returns and this is consistent with the evidence presented in Lown et al. (2000) on the effects of 
Figure 1. Capital Liquidity and Aggregate Merger Activity

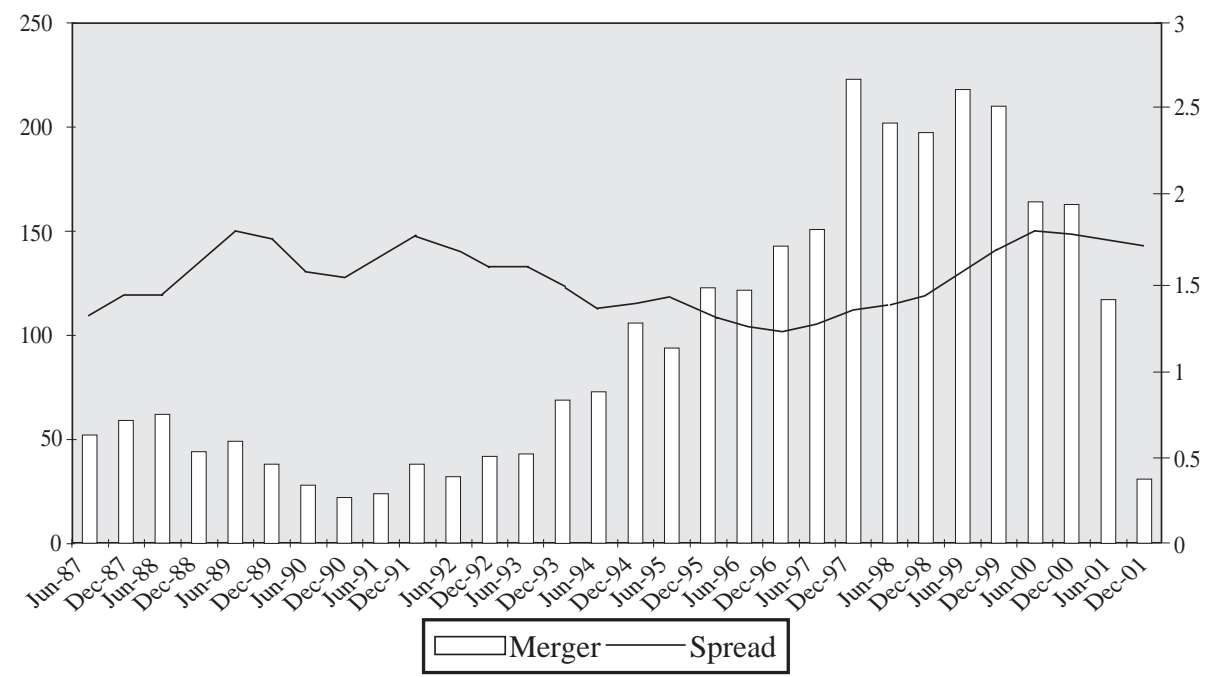

The line in the figure represent the spread between the fed funds rate and the average rate charged for commercial and industrial loans as reported in the Federal Reserve's Survey of Terms of Business Lending (right axis). This spread is measured in percentage points and proxies for low capital liquidity. The vertical bars indicate the total number of merger bids with a transaction value of at least $\$ 50$ million in 2002 dollars (left axis).

Figure 2. Time-series Relation between Variables Commonly Used in Behavioral Explanations of Merger Waves and the Rate Spread Variable

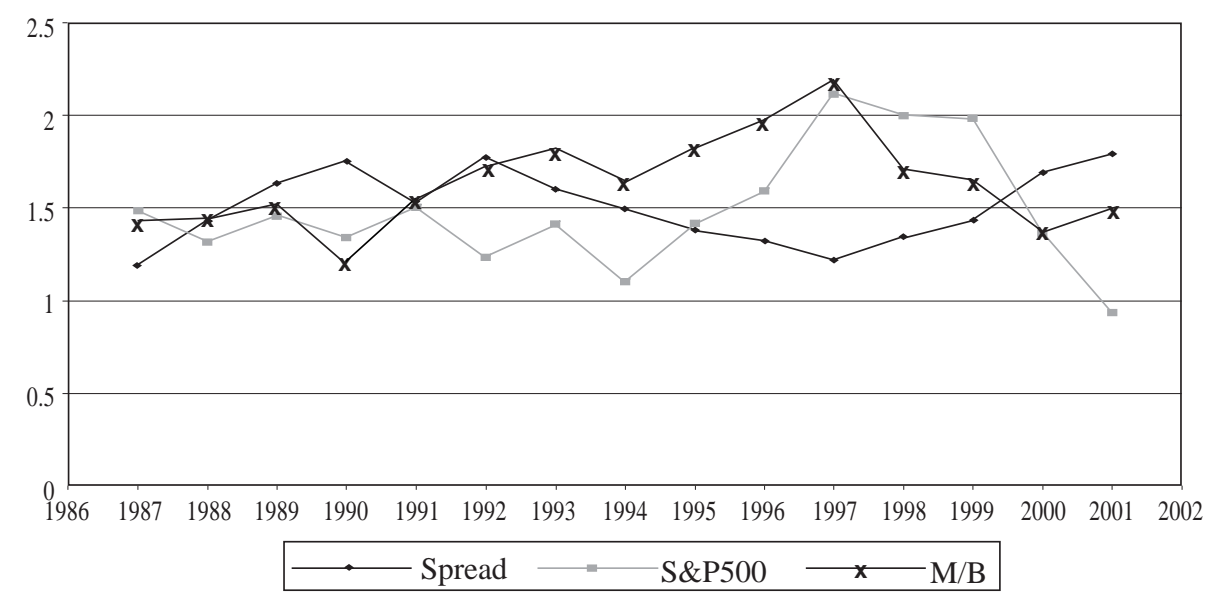

The rate spread is the spread between the average commercial and industrial loan rate and the Fed Funds rate (these two rates are collected by the Federal Reserve in its Survey of Terms of Business Lending). This spread is measured in percentage points and proxies for low capital liquidity. The market-to-book time series is the median market-tobook ratio of all firms on Compustat each year. Lastly, 3-yr S\&P500 Return is one plus the compounded prior threeyear return on the S\&P500 index. All series are scaled to use the left axis. For instance, 1.5 represents a rate spread of 1.5 percentage points, a median market-to-book ratio of 1.5, and 50 percent compound return on the S\&P500 index. 
changes in the ease of credit on overall economic growth.

The results so far are mixed and indicate that economic factors and market-to-book, if counted as behavioral hypothesis variables, drive merger waves. It can be said that observable economic shocks lead to industry merger waves and those merger waves cluster when capital liquidity is relatively high (transaction costs are low) and firms' stocks are overvalued. To distinguish these two interpretations, successive logit models will be employed to predict merger waves. The interpretation of the relation between the behavioral variable and the rate spread is also borne out by the model. Because the behavioral variable is included in the regression, the rate spread will be insignificant if it is actually a proxy for that variable. Alternatively, if the behavioral variable is simply capturing effects correlated with the rate spread, then it will be insignificant.

\section{Logit Models}

The sample of 48 industries for the 12-year sample period is included in the logit model to estimate the start of merger waves. The explanatory variables for the model are taken from those analyzed in Table 3. The industry-specific economic shock variables within an industry, however, are highly correlated and may cause multicollinearity if concurrently incorporated in a regression model. To avoid this potential problem, the first principal component from the seven economic shock variables (profitability, asset turnover, research and development, capital expenditures, employee growth, return on assets, and sales growth) is extracted. It is predicted by the capital liquidity part of the neoclassical hypothesis that these shocks will be less likely to cause a wave when liquidity is low. High liquidity years are defined as the years in which the rate spread is below its time-series median and the industry's market-to-book ratio is simultaneously above its time-series median. Low liquidity years are all other years. In the logit model, the economic shock principal component is entered on its own and interacted with a dummy identifying low liquidity years.

Table 4 presents the results of estimating logit models of the start of merger wave. As shown in the first column of the table, consistent with Harford's finding, the industry market-to-book by itself has some ability to predict merger waves; an increase in the market-to-book ratio will increase the probability of a merger wave. In the second column, the model is estimated using the economic variables only. The shock variable is significantly positive which is consistent with Harford's finding. Furthermore, the shock variable interacted with the dummy variable for low liquidity is insignificant which is inconsistent with the study of Harford that finds the shock variable is negative and significant. The rate spread variable is negative and strongly significant and the 
Soegiharto-Drivers of Merger Waves

Table 4. Predicting Merger Waves

\begin{tabular}{|c|c|c|c|}
\hline & (1) & (2) & (3) \\
\hline Intercept & $\begin{array}{r}-3.194 \\
{[0.000]}\end{array}$ & $\begin{array}{r}-2.147 \\
{[0.000]}\end{array}$ & $\begin{array}{l}{[0.000]} \\
{[0.000]}\end{array}$ \\
\hline $\mathrm{M} / \mathrm{B} t-1$ & $\begin{array}{r}0.333 \\
{[0.000]}\end{array}$ & & $\begin{array}{r}0.616 \\
{[0.000]}\end{array}$ \\
\hline C\&I Rate Spreadt-1 & & $\begin{array}{r}-6.571 \\
{[0.000]}\end{array}$ & $\begin{array}{r}-6.586 \\
{[0.000]}\end{array}$ \\
\hline Deregulatory Eventt-1 & & $\begin{array}{r}1.544 \\
{[0.000]}\end{array}$ & $\begin{array}{r}1.745 \\
{[0.000]}\end{array}$ \\
\hline Econ Shock Index & & $\begin{array}{r}0.3862 \\
{[0.008]}\end{array}$ & $\begin{array}{r}0.209 \\
{[0.139]}\end{array}$ \\
\hline Econ Shock Index (Tight Capital) & & $\begin{array}{r}-1.556 \\
{[0.766]}\end{array}$ & $\begin{array}{r}-1.416 \\
{[0.773]}\end{array}$ \\
\hline
\end{tabular}

Logit models are employed to predict when an industry will have a merger wave. The sample is 48 industries, each over 12 years (1990-2001). The explanatory variables are measured at the end of year $t-1$. Market-to-book is the industry median market-to-book ratio and the commercial and industrial (C\&I) loan rate spread (spread above the fed funds rate) proxies for low capital liquidity. There is also a dummy variable selecting years that were preceded by a major deregulatory event. The economic shock index is the first principal component of the seven economic shock variables in the first column of Table 3 . The shock index is also interacted with a dummy variable selecting years when market-to-book ratios are below their industry-specific time-series median or the C\&I rate spread is above its timeseries median (years of low capital liquidity). The dependent variable is equal to one if the industry-year is the beginning of a merger wave in that industry.

Table 5. The Gap between the Year of Deregulation and the Year of Wave Started for Deregulated Industries

\begin{tabular}{|c|c|c|}
\hline Industry Deregulated & Year of Deregulation & Year of Wave Started \\
\hline Entertainment & 1992 & 1998 \\
\hline Petrol and Natural Gas & 1992 & 1997 \\
\hline Utilities & 1992 & 1997 \\
\hline Communications & 1993 & 1997 \\
\hline Transportation & 1993 & 1997 \\
\hline Transportation & 1994 & 1996 \\
\hline Banking & 1994 & 1997 \\
\hline Transportation & 1995 & 1997 \\
\hline Communications & 1996 & 1997 \\
\hline Utilities & 1996 & 1997 \\
\hline
\end{tabular}


deregulation indicator variable is positive and also strongly significant. The finding on the deregulatory variable is consistent with Harford's (2005) finding that deregulation precedes merger waves in the 1980s and 1990s. This finding is also consistent with Mulherin and Boone (2000) who find a significant and positive effect of deregulation on acquisition activity in the 1990s and Andrade et al. (2001) who find deregulation is a key driver of merger activity over that period. The years at which the major deregulatory events are announced and the starts of the wave are presented in Table 5 . The univariate results confirm that capital liquidity, industry shocks, and deregu- lation propagate merger waves.

The full model, which is estimated in the third column, indicates that the shock variable becomes insignificant and all other variables remain significant. These full models support the argument that merger wave is propagated by the higher capital liquidity, the presence of deregulatory event, and the increase in firms' market-tobook ratio. These findings support the behavioral hypothesis and only part of neoclassical hypothesis.

As in Harford, this study also attempts to answer whether clustering of merger activity at the aggregate level is caused by clustering of industrylevel merger waves. The relation be-

Figure 3. The Relation between Aggregate Merger Activity and Industry Merger Waves

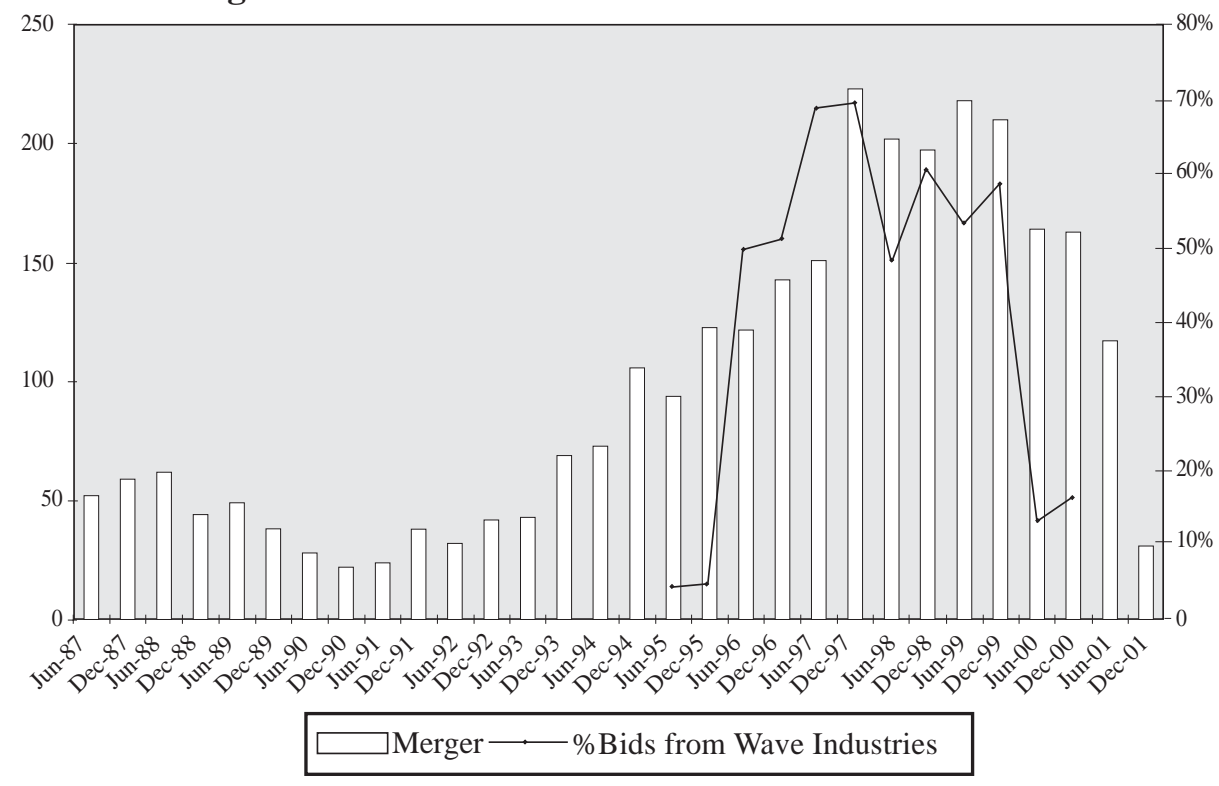

The line indicates the percent of all bids, shown on the right axis, in each year that involved one of the industries undergoing a merger wave in that year The height of each bar represents the number of bids, shown on the left axis, with a deal value of at least \$50 million (2002 dollars) across all industries in that year 
tween aggregate merger activity and the proportion of bids taking place in theindustry-level merger waves is identified and presented in Figure 3. The figure clearly indicates that aggregate merger waves take place when industry-level merger waves cluster in time and that the total merger activity in these waves is driven by bids in the industries experiencing waves. To formally test this observation, the correlation between the total number of merger transactions in the economy and the proportion of bids in industries undergoing industry-specific waves is computed. The correlation between the two factors is highly significant 0.815 .

This study also attempt to further test the relation between the neoclassical explanation of industry level merger waves and overall aggregate merger activity by predicting aggregate merger waves using a specification analogous to that used to predict industry merger waves. In addition, all procedures and tests similar to those used to predict industry merger waves are undertaken. There are only 12 observations (one for each year from 1990 to 2001) included in the tests. The results of the tests, however, all are insignificant due to the small number of observations.

\section{Operating Performance}

Mergers motivated by an economic rationale, as in industry shock mergers, are expected to improve performance. Nevertheless, evidence on this merger is at best mixed (Agrawal and Jaffe 2003) with many studies documenting that bidders return are, on average, negative (Andrade et al. 2001). On the other hand, mergers not motivated by economic factors, as in stock market misvaluation mergers, may result in bidders experiencing abnormally negative long-run returns due to the fact that the firms are overvalued in the first instance, and merged firms enduring especially poor postmerger operating performance.

This section discusses the operating performance test for mergers undertaken in waves. Accounting data, extracted from Compustat database, of the acquirer and target firms prior to the merger are used to calculate the pro forma pre-merger performance of the combined firms. To control for changing industry and economy-wide conditions and for possible mean reversion resulting from abnormal pre-event performance, the industry-adjusted performance of the acquirer and target firms is used as a primary benchmark to evaluate the post-merger performance. Based on the Healy et al.'s study (1992), the pre-merger industryadjusted operating performance and a dummy variable (one for mergers that occur in wave and zero otherwise) are regressed against the post-merger industry-adjusted operating performance. As in Healy et al's study, the average post-merger change in the performance measure is captured by the intercept in the regression. The dummy variable indicates whether wave periods are different from non-wave periods. Because of mean-reversion in in- 
Gadjah Mada International Journal of Business, January - April 2008, Vol. 10, No. 1

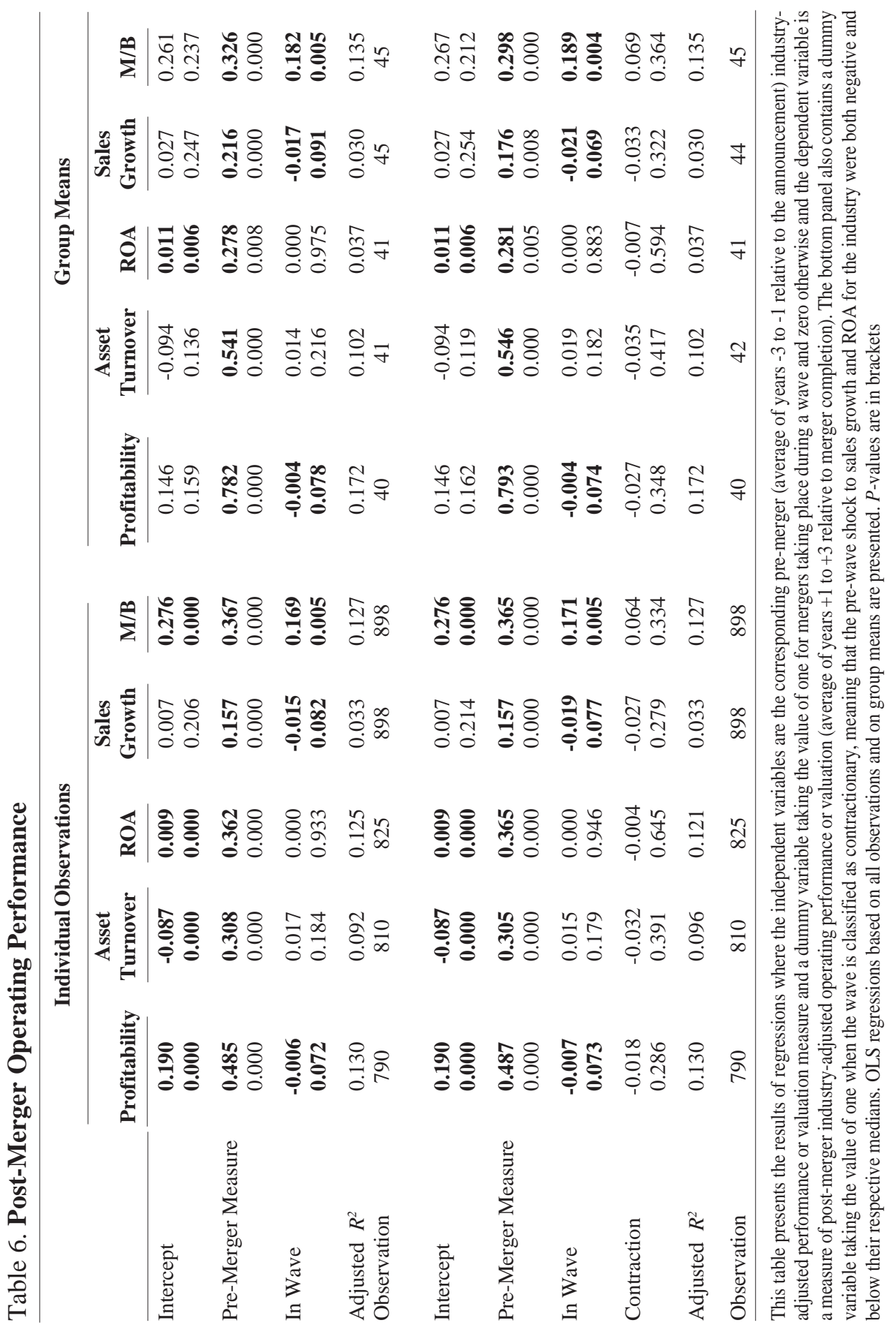


dustry-adjusted operating performance, the slope coefficient is expected to be less than one as discussed in Barber and Lyon (1996).

The results, presented in Table 6, indicate that changes in profitability and sales growth subsequent to mergers in waves are worse than during other periods and change in market-tobook is no worse than during other periods. As can be seen on the wave dummy, the coefficient for market-tobook is positive and significant (at 0.01 level) which means the postmerger changes in market-to-book remains significantly greater inside waves. On the other hand, the coefficient for profitability and sales growth are negative and significant (at 0.1 level). These results suggest that the post-merger sales growth and profitability decrease during the wave. Due to the clustering of merger activity at the industry level, the observations in the regression are not independent. Hence, tests of grouped-mean regression are also undertaken. The results of these tests, however, do not change the overall inferences.

In this study, the wave in which the benchmark performance is likely to be particularly poor is identified to control for the unobservable benchmark problem in operating performance tests. The identification is done by creating a subsample of wave that reacts to contractionary shocks. These shocks occur when the pre-wave change in sales growth and return on assets are both negative and below their medians. Then, the operating performance regressions including a dummy for contractionary waves are reestimated. The results of the regressions show none of the variables are affected by the benchmarking problem and none of the inferences are changed by the inclusion of the contraction dummy.

In general, the results of the operating performance regression are somewhat mixed. On one hand, as indicated by market-to-book variable, merger inside wave produce better post-merger operating performance which is consistent with neoclassical explanation. On the other hand, as shown by sales growth and profitability variables, there is evidence in which mergers in waves perform significantly worse than those outside waves which is consistent with the behavioral explanation.

\section{Conclusion}

This study reexamines whether merger waves that occurred in the period of 1990 to 2001 can be explained by the neoclassical hypothesis or the behavioral hypothesis. This study directly compares the two explanations of merger wave and finds that merger waves may be driven by higher capital liquidity and stock market misvaluation. In addition, the result for deregulatory variable indicates that merger waves take place when deregulation does exist. Overall, merger waves occur at the time the capital liquidity is high, firms' stocks are overvalued, and deregulatory events are present. As indicated by the variables 
Gadjah Mada International Journal of Business, January - April 2008, Vol. 10, No. 1

that related to the neoclassical hypothesis (e.g. ROA), the industry shocks do not propagate merger waves.

It is expected that mergers that preceded by industry shock (economic rational) is capable of improving performance and those that led by market misvaluation (no operational motive) would produce particularly poor postmerger operating performance. The result of firms' post-merger operating performance tests support that both the neoclassical hypothesis and the behavioral hypothesis explain the occurrence of merger waves. As indicated by market-to-book variable, mergers inside waves produce better post-merger operating performance which is consistent with neoclassical explanation and as shown by sales growth and profitability variables, there is evidence in which mergers in waves perform significantly worse than those outside waves which is consistent with behavioral explanation.

\section{References}

Agrawal, A., and J. F. Jaffe. 2003. Do Takeover Targets Underperform? Evidence from Operating and Stock Returns. Journal of Financial and Quantitatvie Analysis 38 (4):721-746.

Andrade, G., M. Mitchell, and E. Safford. 2001. New Evidence and Perspectives on Mergers. Journal of Economic Perpectives 15 (2):103-120.

Andrade, G., and E. Stafford. 2004. Investigating the Economic Role of Mergers. Journal of Corporate Finance 10 (1):1-36.

Ang, J. S., and Y. Cheng. 2003. Direct Evidence on the Market-Driven Acquisitions Theory. Working Paper, Florida State University.

Barber, B. M., and J. D. Lyon. 1996. Detecting Abnormal Operating Performance: The Empirical Power and Specification of Test Statistics. Journal of Financial Economics 41 (3):359-399.

Becketti, S. 1986. Corporate Mergers and the Business Cycle. Federal Reserve Bank of Kansas City Economic Review:13-26.

Clark, K., and E. Ofek. 1994. Mergers as a Means of Restructuring Distressed Firms. An Empirical Investigation. Journal of Financial and Quantitatvie Analysis 29 (4):541565.

Dong, M., D. Hirshleifer, S. Richardson, and S. H. Teoh. 2002. Does Investor Misvaluation Drive the Takeover Market? Working Paper. Ohio State University.

Eisfeldt, A., and A. Rampini. 2003. Capital reallocation and liquidity. In Unpublished working paper: Northwestern University.

Fama, E., and K. French. 1997. Industry costs of equity. Journal of Financial Economics 43:153-193.

Golbe, D., and L. J. White, eds. 1988. A Time Series Analysis of Mergers and Acquisitions in the U.S. Economy. Edited by A. J. Auerbach. Chicago, IL.: University of Chicago Press/NBER. 


\section{Soegiharto-Drivers of Merger Waves}

Gort, M. 1969. An Economic Disturbance Theory of Mergers. Quarterly Journal of Economics 83 (4):624-642.

Harford, J. 2003. Efficient and Distortional Components to Industry Merger Waves. Working Paper, University of Washington.I

- 2005. What drives merger waves? Journal of Financial Economics 77:529-560.

Healy, P., C. Palepu, and R. Ruback. 1992. Does Corporate Performance Improve after Mergers? Journal of Financial Economics 31 (2):135-175.

Jensen, M. C. 1993. The Modern Industrial Revolution, Exit, and Control Systems. Journal of Finance 48:831-880.

Lown, C., Morgan, D., Rohatgi, S. 2000. Listening to loan ofûcers: The impact of commercial credit standards on lending and output. FRBNY Economic Policy Review.

Melicher, R. W., J. Ledolter, and L. J. D’Antonio. 1983. A Time Series Analaysis of Aggregate Merger Activity. Review of Economics and Statistics 65 (423-430).

Mitchell, M. L., and H. J. Mulherin. 1996. The Impact of Industry Shocks on Takeover and Restructuring Activity. Journal of Financial Economics 41 (2):193-229.

Morck, R., A. Shleifer, and R. Vishny, eds. 1988. Characteristics of Targets of Hostile and Friendly Takeover. Edited by A. J. Auerbach. Chicago, IL.: University of Chicago Press/National Bureau of Economic Research.

Mulherin, J. H., and A. L. Boone. 2000. Comparing Acquisitions and Divestitures. Journal of Corporate Finance 6:117-139.

Nelson, R. L. 1959. Merger Movements in American Industry, 1895-1956. Princeton, NJ.: Princeton University Press.

Rhodes-Kropf, M., D. T. Robinson, and S. Viswanathan. 2004. Valuation Waves and Merger Activity: The Empirical Evidence. Working Paper, Columbia University.

Rhodes-Kropf, M., and S. Viswanathan. 2004. Market Valuation and Merger Waves. Journal of Finance 59 (6):2685-2718.

Shleifer, A., and R. W. Vishny. 2003. Stock Market Driven Acquisitons. Journal of Financial Economics 70 (3):295-311.

Shleifer, A., Vishny, R. 1992. Liquidation values and debt capacity. Journal of Finance 32:337-347.

Switzer, J. A. 1996. Evidence on Real Gains in Corporate Acquisitions. Journal of Economics and Business 48.

Verter, G. 2002. Timing Merger Wave. Working Paper. Harvard University. 